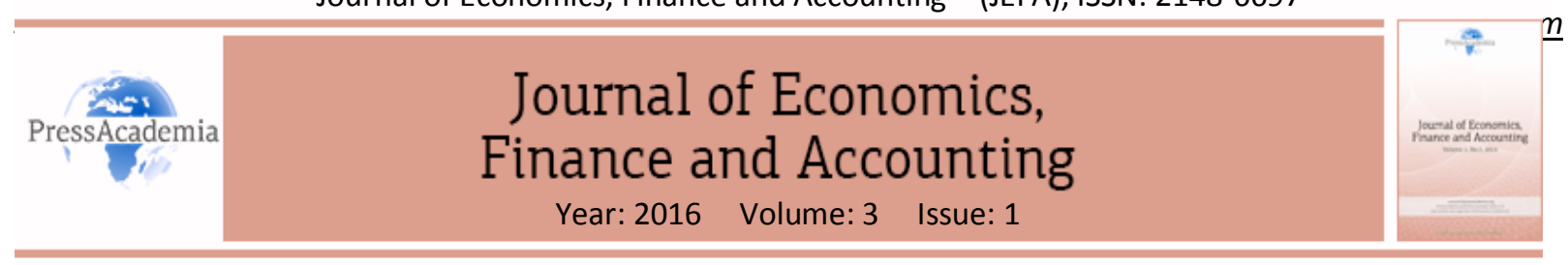

\title{
DETERMINING THE RELATION BETWEEN FINANCIAL PERFORMANCE AND STOCK RETURNS OF ENERGY COMPANIES ON BORSA ISTANBUL WITH PANEL DATA ANALYSIS
}

DOI: 10.17261/Pressacademia.2016116537

Sakir Sakarya ${ }^{1}$, Hasan Huseyin Yildirim ${ }^{2}$

'Balikesir University. sakarya@balikesir.edu.tr

2Balikesir University. hhyildirim@balikesir.edu.tr

\begin{abstract}
In this study examined the relationship between financial performance and stock returns of fourteen energy companies active in Borsa Istanbul has been examined. In this context, firstly ten ratios Which were drawn from financial statements of these companies, determined and all the determined ratios were calculated separately for each company. By using the TOPSIS method, one of the multi-criteria decision analysis (MCDA), the calculated ratios were first converted into TOPSIS scores which reflects general company performance. After that, the relationship between TOPSIS scores and average annual returns of the companies were tested by panel data analysis. The conclusion that there is a short-term cointegration between TOPSIS score and stock returns of companies has been inferred from the test results. However, mutual causality between TOPSIS scores and stock returns result has not been encountered.
\end{abstract}

Keywords: Energy sector, performans analysis, TOPSIS method, panel causality test.

JEL Classification: C02, C23, G39

\section{BORSA ISTANBUL'DA IŞLEM GÖREN ENERJi ŞIRKETLERININ FINANSAL PERFORMANSLARI ILE HISSE SENEDi GETiRILERI ARASINDAKi iLIŞKININ PANEL VERi ANALIZi iLE BELIRLENMESi}

\section{ÖZET}

Bu çalışmada, hisse senetleri Borsa İstanbul'da işlem gören on dört enerji şirketinin finansal performansları ile hisse senedi getirileri arasındaki ilişki incelenmiştir. Bu bağlamda öncelikle şirketlerin finansal tablolarından yararlanılarak on adet oran belirlenmiş ve belirlenen oranlar her bir şirket için ayrı ayrı hesaplanmıştır. Hesaplanan oranlar; ilk önce Çok Kriterli Karar Verme Yöntemleri (ÇKKVY)'nden birisi olan TOPSIS yöntemi kullanılarak genel şirket performansını gösteren TOPSIS skorlarına dönüştürülmüştür. Daha sonra TOPSIS skorları ile şirketlerin yıllık ortalama getirileri arasındaki ilişki panel veri analizi ile test edilmiştir. Test sonuçlarında şirketlere ait TOPSIS skorları ile hisse senedi getirileri arasında kısa dönemli bir eş-bütünleşme olduğu sonucuna ulaşılmıştır. Ancak TOPSIS skorları ile hisse senedi getirileri arasında karşılıklı bir nedensellik sonucuna rastlanıımamıştır.

Anahtar Kelimeler: Enerji sektörü, performans analizi, TOPSIS yöntemi, panel nedensellik testi

JEL Sinıflandırması: C02, C23, G39 


\section{GiRiş}

Enerji, en basit tanımıyla iş yapabilme yeteneğidir. Enerjiye olan ihtiyaç, tarih boyunca hep var olmuştur. Önceleri hayatta kalmak için kas gücüyle elde edilen enerji, zamanla doğal kaynaklar ve yakıt kullanarak, artan nüfus, insan ihtiyaçları ve teknolojiyle birlikte büyük bir hızla artmıştır. Sanayi devrimiyle birlikte endüstri makineleşmiş, dolayısıyla enerjiye olan bakış açısı yeni bir boyut kazanmıştır. Endüstriyi besleyen enerji için hammadde arayışları ülkelerin stratejilerini değiştirmiş, savaşlar çıkmış ve enerji bir güç kaynağı haline gelmiştir.

Enerjinin gündelik yaşamdaki yerinin ve etkinliğinin artması; enerji sektörünün iş hacmini çoğaltırken, yapısını da daha dinamik hale dönüştürmektedir. Ayrıca bu durum enerjinin ekonomiler içindeki payını ve önemini arttırmakta ve ülkelerin uluslararası ilişkilerine doğrudan veya dolaylı olarak etkide bulunmaktadır.

Türkiye'de rekabetçi, mali açıdan güçlü, istikrarlı ve şeffaf bir enerji piyasası oluşturmak amacıyla Enerji Piyasası Düzenleme Kurumu (EPDK) kurulmuştur. Böylece, enerji piyasası, kurumsallaşmasını tamamlayarak, piyasanın düzenlenmesini ve denetlemesini organize bir yapı içinde gerçekleştirme imkanı elde etmiştir. Ülkemizde enerji piyasası ile ilgili olarak gerekli yasal düzenlemeler tamamlanmıştır. EPDK, gerçekleştirdiği faaliyetleri ile enerji sektörünün gelişmesinde önemli bir rol üstlenmektedir (Ergül, 2010).

Çalışmamızda öncelikli olarak, finansal oranların performans ölçümü olarak kullanılması ve hisse senedi getirileri ile olan ilişkiden kısaca bahsedilmiştir. Çalışmanın devamında ulusal ve uluslararası yapılmış benzer çalışmaların yer aldığı literatür kısmına yer verilmiştir. Daha sonra çalışmada kullanılacak olan veri seti ve yapılacak testler açıklanmıştır. Çalışmanın uygulama kısmında da 2010-2014 döneminde Borsa İstanbul'da işlem gören enerji şirketlerinin finansal performansları TOPSIS yöntemi ile analiz edilerek her yıl için şirketlere ait TOPSIS skorları elde edilmiştir. Yine 2010-2014 yılları arasında her yıl için şirketlerin hisse senedine ait yıllık ortalama getirileri hesaplanmıştır. Borsa İstanbul'da işlem gören 14 şirketin 5 yıllık TOPSIS skorları ile hisse senedi getirileri arasında ilişki panel veri analizi test edilmiştir.

\section{FINANSAL ORANLARIN PERFORMANS ÖLÇÜMÜ OLARAK KULLANILMASI VE HISSE SENEDi GETiRILERI iLE ILIŞKISi}

Performans ölçümünde kullanılan yöntemlerden en yaygın ve uygulaması kolay olanı oran analizidir. Tek girdinin tek çıktıya oranı olarak tanımlanan oran analizi (ya da rasyo analizi) yaklaşımında her bir oran, performansla ilgili boyutlardan bir tanesini göz önüne almaktadır.

Finansal oranlar, işletmelerin likidite, büyüme, karlılık gibi temel konularda güçlü ve zayıf taraflarının belirlenmesini sağlamaktadır (Hitchner,2003). Finansal oranlar yardımıyla işletmelerin durumunu karşılaştırmak da mümkün olmaktadır. Bu karşılaştırma iki şekilde yapılmaktadır. Bunlardan ilki işletmeyi kendi içinde karşılaştırmak, ikinci ise işletmeyi sektördeki kendine benzer bir başka işletme ile karşılaştırmaktadır (Crowther,2004)

İşletmenin performansını kendi içinde karşılaştırırken, işletmenin geçmiş yıllara ait oranları kullanılmakta ve bunların yıllar itibariyle gösterdiği değişiklik dikkate alınmaktadır. Ayrıca bütçe hedeflerinin karşılanıp karşılanmadığına da bakılmaktadır (Uygurtürk\& Korkmaz, 2012). İşletmenin bir başka işletme ile performans karşılaştırması durumunda ise ilgili oranlar aynı zaman aralığında her iki işletme için hesaplanmaktadır. Dolayısıyla işletmelerin mali tablolarındaki aynı iki finansal verinin oran değerleri karşılaştırmaya konu olduğundan, işletmelerin performans karşılaştırması rahatlıkla yapılabilmektedir (Walton,2000). Finansal oranlar, geniş bir kullanıcı kitlesine sahiptir. Bu kullanıcı kitlesinin başında kreditörler, işletme yöneticileri, mevcut veya potansiyel ortaklar, finansal analistler ve akademik araştırmacılar gelmektedir (Osteryoung\&Constand, 1992)

Finansal oranlar şirket performansının ölçümünde kullanılmasının yanında hisse senedi getirileri arasındaki ilişki finans disiplininde pek çok araştırmacının ilgisini çekmiştir. Yatırımcılar hisse senetlerine yatırım yaparken getirilerini etkileyen firmalara ait finansal oranları doğru anlamalı ve doğru bir şekilde analiz etmelidir.

\section{LITERATÜR}

TOPSIS yöntemi her sektörde kullanılabilecek ve karar vermeyi kolaylaştıran bir yöntem olarak finans literatüründe yerini almıştır. Özellikle, 1970'li yıllardan sonra şirketlerin finansal performanslarının ölçülmesi ve 
değerlendirilmesinde kullanılmaya başlanmıştır. TOPSIS yöntemi ve finansal oranlar ile hisse senedi arasındaki ilişkiyi inceleyen ampirik çalışmalardan bazıları aşağıda özetlenmektedir.

Çonkar, vd. (2011) çalışmalarında Borsa isstanbulda yer alan büyük ölçekli on adet şirketin finansal oranlarını kullanarak 2007 ve 2008 yılları için şirketlerin finansal performanslarını TOPSis yöntemi ile belirlemişlerdir. Nihai olarak şirketlerin TOPSiS sonuçları ile derecelendirme kuruluşlarının şirketlere verdikleri kurumsal yönetim notu karşılaştırılmıştır.

Deng, Yeh\&Willis (2000) Çin'de şirket değerlendirmesinde kullanılan finansal oranların anlamlı ve yararlı bilgileri sağlayarak, verilecek kararlarda etkin rol oynadıkları için finansal oranları kullanarak, şirket içi performansların ölçümünde ve değerlendirilmesinde TOPSIS yönteminin basit ve etkili bir yol olduğunu ortaya koymuşlardır.

Feng \&Wang (2000) havayolu işletmelerinin performansını inceledikleri çalışmalarında, beş Tayvan havayolu şirketinin ulaştırma ve finansal göstergeleri olarak toplam 22 değişken kullanarak TOPSIS yöntemini uygulamışlar ve bu işletmelerin performanslarının değerlendirilmesinde finansal göstergelerin daha etkili olduğu sonucuna ulaşmışlardır.

Acar (2003) çalışmasında; 150 civarında işletme üzerinde 11 oran ile finansal performans analizi yapmıştır. Ayrıca çalışmada içe dönük ve dışa dönük analizlerden bahsedilmiş ve sonuç olarak finansal oranların finansal performansa etkilerinin önemlilik düzeyleri tespit edilmiştir.

Yurdakul ve iç (2003); Türkiye'de otomotiv sektöründe faaliyet gösteren ve iMKB'ye kayıtlı 5 büyük işletmenin 1998-2001 finansal tablolarından elde edilen finansal oranları kullanarak firmaların derecelendirilmesine yönelik bir model geliştirmiş ve TOPSIS yöntemi yardımıyla genel firma performansını gösteren tek bir puana çevirmiştir. Çalışma sonucunda; söz konusu işletmelerin IMKB'deki hisse değerleri ile TOPSIS yönteminden elde edilen sonuçlar birbiriyle tutarlı çıkmışır.

Yalçıner vd. (2005) firmaların ilgili dönem rasyoları ile hisse senedi getirileri arasındaki ilişkinin belirlenmesi amacıyla Veri Zarflama Analizi (VZA) ve Malmquist Toplam Faktör Verimliliği (TFV) analizi yapılmışıı. VZA sonuçlarına göre, etkin olan şirketlerle onların hisse senedi getirileri arasındaki ilişki, ekonomik istikrarın sağlandığı dönemlerde yüksek derecede çıkmıştır. TFV indeksi unsurları bazında yapılan analizde, Teknik Etkinlik Değişimi - Teknolojik Değişim ve Teknik Etkinlik Değişimi - Ölçek Etkinliği Değişimi unsurlarında artı̧̧ olan hisse senetlerinin pozitif getiri elde etme olasılığı çok yüksek çıkmışır.

Kalaycı ve Karataş (2005) yaptıkları çalışmada, hisse senedi getirileri ile finansal oranlar arasındaki ilişkiler temel analiz yaklaşımı çerçevesinde incelenmiştir. Çalışmada, metod olarak faktör ve regresyon analizleri kullanılmıştır. Çalışma, imalat sanayi alt sektörleri olan gıda ve içecek; kimya, petrol ve plastik ürünler ve orman, kağıt ve basım sektörlerini kapsamaktadır. 1996-1997 yılları için, şirketlerin 6 aylık periyotlarla açıklanan mali tablolarından elde edilen kârııık, faaliyet, finansal kaldıraç, likidite ve borsa performansı oranları kullanılarak, bu sektörlerdeki firmaların ilgili dönemde hisse senedi getirileri açıklanmaya çalışıımıştı. Araşııma sonucunda, ilgili sektörlerde hisse senedi getirilerinin kârılıık, borsa performansı ve verimlilik oranlarıyla açıklandığı görülmüştür.

Shih, Shyur\& Lee (2007) yerel bir kimya şirketinin insan kaynaklarında personel seçimi için TOPSIS yöntemini kullanmışlar ve karar vermede TOPSIS yönteminin güçlü bir yöntem olduğunu ortaya koymuşlardır.

Mahmoodzadeh vd.(2007) çalışmalarında net bugünkü değer, getiri oranı, fayda maliyet analizi ve geri ödeme süresi gibi geleneksel proje değerlendirme yöntemleri ile FAHP ve TOPSIS metotlarını kullanarak farkı projelerin tercih sıralamasını belirlemişlerdir.

Eleren\&Karagül (2008) Türkiye ekonomisinin performansının değerlendirilmesine yönelik çalışmalarında, 19862006 dönemi içinde 7 tane temel ekonomik göstergeden hareketle TOPSIS yöntemi ile her yıla ait tek bir performans puanı belirlemeye çalışmışlar ve 1986 yılının en iyi, 1999 yılının ise en kötü ekonomik performansın görüldüğü yıllar olarak tespit etmişlerdir.

Bülbül\& Köse (2009) gıda sektörünün finansal performansının hem tüm sektör hem de şirket bazında değerlendirilmesinde TOPSIS ve ELECTRE yöntemlerini kullanmışlar ve bu yöntemlerin finansal performans değerlendirilmesinde sağlıklı sonuç alınmasına imkan verdiklerini ortaya koymuşlardır. 
Ergül (2010) Borsa İstanbul'da işlem gören enerji şirketlerinin mali performanslarının değerlendirilmesinde TOPSIS yöntemini kullanmış ve TOPSIS yönteminin enerji sektörünü ve sektörde faaliyette bulunan şirketlerin mali analizde başarılı bir şekilde kullanılabileceğini ifade etmiştir.

Dumanoğlu \& Ergül (2010) da yaptıkları çalışmalarında 2006-2009 sürecinde Borsa İstanbul'da işlem gören onbir teknoloji şirketinin mali tablolarını kullanmışlardır. Şirketlerin mali performansları 8 adet rasyo kullanılarak TOPSIS yöntemi ile analiz edilmiştir. Sonuç olarak teknoloji şirketlerinin mali performanslarına ilişkin analiz sonuçlarının temel analiz sonuçlarını doğrular nitelikte olduğuna ulaşmışlardır. Dolayısıyla TOPSIS yönteminin finansal performans ölçümünde başarılı bir şekilde sonuç verdiğini doğrulamışlardır. Teknoloji sektöründe faaliyette bulunan benzeri şirketlerin aynı kriterler ile karşılaştıılarak mali başarılarının belirlenmesi ve sıralanmasına imkan veren TOPSIS yöntemi; teknoloji şirketlerinin mali performansının hem sektör için hem de şirket bazında daha başarılı değerlendirilmesine olanak sağladığı sonucuna ulaşmışlardır.

Şalvarcı (2010) çalışmasında, imalat sektöründeki şirketlerde bağımsız değişken olarak finansal oranlardan 20 adet oran kullanılarak hisse senetleri ile getirileri ve finansal oranlar arasındaki ilişkinin doğrusal olup olmadığını test etmiştir. Analizinde biri doğrusal model ve dokuz tanesi doğrusal olmayan model olmak üzere toplam 10 adet farklı model kullanmışır. Çalışmasının sonucunda hisse senetleri ile finansal oranlar arasında çoğunlukla doğrusal olmayan ilişkinin varlığını tespit etmiştir.

Yükçü \&Atağan (2010) yıllarında yaptıkları çalışmalarında bir holdinge bağlı aynı sektörde faaliyet gösteren üç işletme için performans göstergeleri olarak TOPSIS yöntemi kullanılarak hangi işletmenin daha iyi performans gösterdiği ölçülmeye çalışılıışır. Çalışmanın sonucu ilgili holdinge ait 3 işletmeyi 4 farkı değerlendirme ölçüsüne göre yapılan analizde şirketlerin performanslarına göre sıralaması yapıImıştır. Çalış̧ma sonucunda TOPSIS yöntemi karar vericiye farklı değerlendirme seçeneklerini ortak bir paydada birleştirebildiği için daha objektif bir değerlendirme yapılabilme imkanı sağladığı sonucuna ulaşmışlardır.

Karaca ve Başcı (2011) çalışmalarında, IMKB 30 endeksinde 2001-2009 dönemi için panel veri analizi kullanarak hisse senedi getirileri ile finansal rasyolar arasında bir ilişkinin olup olmadığıı test etmişlerdir. Net kar marjı, esas faaliyet kar marjı, varlıkların devir hızı ve özsermayenin devir hızı rasyolarının istatistiki açıdan hisse senedi getirilerini açıkladıklarını bulmuşlardır.

Uygurtürk\&Korkmaz (2012) Borsa İstanbul'da işlem gören 13 ana metal sanayi işletmesinin 2006-2010 dönemine ait mali tablolarını kullanılarak, işletmelerin finansal performanslarını TOPSIS yöntemi ile analiz etmişlerdir. Öncelikle işletmelerin finansal güçlülüğünü ortaya koymak amacıyla finansal oranlar hesaplanmış, daha sonra hesaplanan oranlar; TOPSIS yöntemi kullanılarak genel şirket performansını gösteren tek bir puana çevrilmiştir. Hesaplanan performans puanları işletmelerin sıralandırımasında kullanılmışıı. Çalışma sonucunda, ana metal sanayi sektöründe faaliyette bulunan işletmelerin performans puanlarının analiz döneminde genel olarak değişkenlik gösterdiği tespit edilmiştir.

Akbulut ve Rençber 2015 yılında yapmış oldukları çalışmada; Borsa i̇stanbul'da işlem gören İmalat sektöründeki 32 işletmenin 2010-2012 dönemini kapsayan üç yıllık finansal performansları ile pazar değeri/defter değeri oranları karşılaştııımıştır. Analizde finansal performansı ölçmek için 10 adet değişken ve borsa performansı için pazar değeri/defter değeri oranı kullanılarak TOPSIS yöntemi ile performans değerlendirilmesi gerçekleştirilmiştir.

\section{VERI SETI}

Enerji şirketlerinin mali performanslarını incelemek üzere 2010-2014 döneminde hisse senetleri Borsa İstanbul'da işlem gören 14 enerji şirketinin finansal tabloları ve yıllık ortalama getirileri çalışma kapsamına dahil edilmiştir. 5 yıllık süreçte finansal oranların hesaplanmasında kullanılan bilgiler, Borsa İstanbul'un ve Kamuyu Aydınlatma Platformu'nun (KAP) resmi internet sitelerinde yayınlanan mali tablolardan elde edilmiştir(Borsa İstanbul, 2015; KAP, 2015). Hisse senedi getirilerini elde etmek için ise hisse senetlerinin günlük kapanış fiyatları kullanıımışır. Hisse senedi günlük kapanış fiyatları mynetten elde edilmiştir. Analiz kapsamında performansları analiz edilecek enerji şirketleri Tablo1'de verilmiştir. 
Tablo 1: Çalışma Kapsamına Alınan Enerji Şirketleri

\begin{tabular}{|l|l|}
\hline Borsa Kodu & Şirketin Adı \\
\hline AKENR & AKENERJi ELEKTRIK ÜRETIM A.Ş \\
\hline AKSEN & AKSA ENERJi ÜRETIM A.Ş \\
\hline AKSUE & AKSU ENERJi VE TICARET A.Ş \\
\hline ANELE & ANEL ELEKTRIK PROJE TAAHHÜT VE TICARET A.Ş \\
\hline AVTUR & AVRASYA PETROL VE TURISTIK TESISLER YATIRIMLAR A.Ş \\
\hline AYEN & AYEN ENERJi A.Ş \\
\hline AYGAZ & AYGAZ A.Ş \\
\hline EMKEL & EMEK ELEKTRIK ENDÜSTRISI A.Ş \\
\hline GEREL & GERSAN ELEKTRIK TICARET VE SANAYI A.Ş \\
\hline IPEKE & IPEK DOĞAL ENERJi KAYANAKLARI ARAŞTIRMA VE ÜRETIM A.Ş \\
\hline PETKM & PETKIM PETROKIMYA HOLDING A.Ş \\
\hline TRCAS & TURCAS PETROL A.Ş \\
\hline TUPRS & TÜPRAŞ TÜRKIYE PETROL RAFINELERI A.Ş \\
\hline ZOREN & ZORLU ENERJI ELEKTRIK ÜRETIM A.Ş \\
\hline
\end{tabular}

\section{ARAŞTIRMA YÖNTEMI}

Oran analizi, şirketlerin mali performanslarının değerlendirmesinde, bilanço ve gelir tablolarında yer alan kalemler arasındaki ilişkilerin zaman içerisinde oluşturdukları eğilimlerinin incelenmesinde kullanılmaktadır. Oran analizi, şirketlerin mali tablolarında yer alan kalemler arasındaki ilişkileri daha anlamlı duruma getirmektedir. Bu nedenle, iki mutlak performans göstergesi arasında göreli ilişki kuran "Oran Analizi”nden faydalanılmıştır. Araştırmada, şirketlerin mali performansını ortaya çıkartacak oranların seçimine dikkat edilmiştir.

Araştırmanın analizi üç aşamadan oluşmaktadır. Analizin ilk adımında; enerji sektörünün performansını açıklayacak finansal oranlar belirlenmiş ve ardından oran analizi metodu kullanılarak, finansal oranlar her bir enerji şirketi için ayrı ayrı hesaplanmıştır. İkinci adımda ise, enerji şirketleri için hesaplanan finansal oranlar Çok Amaçıı Karar Verme Yöntemlerinden en yaygın kullanılan TOPSIS yöntemi kullanılarak, genel şirket performansını gösteren tek bir puana çevrilmiştir. Ardından 3. aşamada şirketlerin yıllık ortalama hisse getirileri ile TOPSIS sonucu elde edilen skorlar arasında bir eş-bütünleşme ve nedenselliğin olup olmadığı test edilmiştir.

Çalışma kapsamına dahil edilen finansal oranlar Tablo 2'de kodlanarak listelenmiştir.

Tablo 2: Finansal Oranlar ve Kodları

\begin{tabular}{|c|c|l|l|}
\hline NO & KOD & ORANLAR & (Dönen Varlıklar / Kısa Vadeli Yükümlülükler) \\
\hline $\mathbf{1}$ & L1 & Cari Oran & (Toplam Yabancı Kaynaklar / Toplam Pasif(Aktif)) \\
\hline $\mathbf{2}$ & B1 & Finansal Kaldıraç Oranı & Özkaynaklar/Pasifler(Aktifler) \\
\hline $\mathbf{3}$ & B2 & Özkaynaklar/Pasifler(Aktifler) & ( Özkaynaklar/ Toplam Yabancı Kaynaklar ) \\
\hline $\mathbf{4}$ & B3 & Finansman Oranı & ( KVYK/ Toplam Pasifler ) \\
\hline $\mathbf{5}$ & B4 & KVYK/Toplam Pasifler & Duran Varlıklar / (Özkaynaklar+UVYK) \\
\hline $\mathbf{6}$ & B5 & Duran Varlıklar / Devamlı Ser. & (Net Satışlar / Aktifler ) \\
\hline $\mathbf{7}$ & F1 & Aktif Devir Hızı & (Net Satışlar / Özkaynaklar) \\
\hline $\mathbf{8}$ & F2 & Özkaynak Devir Hızı & (Net Kar/ Özkaynak) \\
\hline $\mathbf{9}$ & K1 & Öz Sermaye Karlılı̆ı̆ & (Net Kar/ Toplam Aktifler) \\
\hline $\mathbf{1 0}$ & K2 & Aktif Karlılığı & \\
\hline
\end{tabular}

Araştırma kapsamına alınan ve Borsa İstanbul'da enerji sektörünün mali analizinde kullanılan finansal oranlar aşağıda açıklanmaktadır. 
Cari Oran: Finansal performans analizlerinde kullanılan en yaygın oranlardan biri olan cari oran, dönen varlıkların kısa vadeli yabancı kaynaklara bölünmesiyle elde edilir. Şirketin kısa vadeli yabancı kaynaklarını ödeyebilme kapasitesinin (Net İ̧letme Sermayesi) değerlendirilmesinde kullanılmaktadır(Akdoğan\&Tenker, 2010).

Finansal Kaldıraç Oranı: Toplam yabancı kaynakların toplam aktiflere oranıdır. Şirketlerin aktiflerinin yüzde kaçının borçlarla finanse edilmekte olduğunu gösterir. Bu oranda meydana gelecek değişiklik, özsermaye karlıı̆ı̆ını da değiştirecektir(Berk, 2007).

Özkaynaklar / Pasifler (Aktifler): Kaynakların ne kadarının özkaynaklardan oluştuğunun göstermektedir. Özkaynakların aktif toplamına oranı varlıkların yüzde kaçının işletme sahip ve ortakları tarafından finanse edildiğini ortaya koyar. Oran işletmenin uzun vadeli borç ödeme gücünü ortaya koyar. Oranın yüksek olması işletmenin uzun vadeli borçlarını ve bunların faizlerini ödemede herhangi bir güçlükle karşılaşmayacağını belirtir. Başka bir anlatımla, işletmeye kredi verenlerin emniyet marjının yeterli olduğunu gösterir. Bu oranın zaman içerisinde yükselme eğilimi göstermesi, genelde yönetimin başarısı olarak değerlendirilir.

Finansman Oranı: Bu oran, özkaynakların, kısa ve uzun vadeli yabancı kaynaklar toplamına bölünmesi ile elde edilir. İşletmenin mali bağımsızlık derecesini gösteren oran, ödeme gücü katsayısı, borçlanma katsayısı veya finansman oranı adları ile de ifade edilmektedir. Finansman oranının yüksek olması; işletmeyi, alacakı durumunda bulunan üçüncü kişilerin baskısından kurtarır.

KVYK / Toplam Pasifler: İ̧letme varlıklarının yüzde kaçının kısa vadeli yabancı kaynaklarla finanse edildiğini gösterir. Oranın yüksek olması, aktifin büyük bir bölümünün kısa vadeli yabancı kaynaklarla finanse edilmiş olduğunu gösterir. Duran varlık grubunun kısa vadeli yabancı kaynaklarla finanse edilmesi hiç arzulanmaz.

Duran Varlıklar / Devamlı Sermaye: Duran varlıkların ne ölçüde uzun vadeli yabancı kaynaklar ve özkaynaklarla finanse edildiğini gösterir. Oranın 1'den küçük olması istenir. Oranın 1'den büyük olması duran varlıkların bir kısmının kısa vadeli yabancı kaynaklarla finanse edildiğini gösterir.

Aktif Devir Hızı: İ̧letmenin sahip olduğu tüm varlıkların verimliliğinin ölçümünde kullanılan bir orandır. Oranın düşük olması, işletmenin tam kapasite ile çalışmadığını gösterir.

Özkaynak Devir Hızı: Özsermayenin ne ölçüde verimli kullanıldığını belirten bir göstergedir. Oranın yüksek olması; işletme özsermayesinin çok ekonomik ve verimli bir biçimde kullanıldığını belirtir.

Öz Sermaye Karlıı̆̆ı: İşletmenin öz sermayesini verimlendirme derecesini gösteren orandır. İşletme sahip ve sahipleri tarafından sağlanan kaynağın bir birimine düşen kar payını göstermektedir. İşletmenin yönetimindeki başarı derecesi ile karlılık durumunun analizinde, anılan oran, önemli bir göstergedir.

Aktif Karlıı̆ı: Varlıkların işletmede ne ölçüde verimli kullanılıp kullanılmadığının saptanmasında kullanılır.

Borsa isstanbul'da işlem gören "AKENR, AKSEN, AKSUE, ANELE, AVTUR, AYEN, AYGAZ, EMKEL, GEREL, IPEKE, PETKM, TRCAS, TUPRS, ZOREN" borsa kodlu enerji şirketlerinin, enerji sektöründeki mali performanslarının ölçülmesi ve değerlendirilmesi amacıyla "Cari Oran, Finansal Kaldıraç Oranı, Özkaynaklar/Aktifler, Finansman Oranı, KVYK/Toplam Pasifler, Duran Varlıklar / Devamlı Sermaye, Aktif Devir Hızı, Özkaynak Devir Hızı, Özsermaye Karlııı̆ı, Aktif Karlılı̆ı"” oranlarından yararlanılmıştır.

Çalışmada bu oranlar seçilirken diğer bazı oranlarda denenmiştir. Örneğin; Asit-Test Oranı, Stok Devir Hızı, Stok Bağımlıık Oranı gibi oranlar stoklar kalemine bağlı olarak analizi yapılan oranlardır. Ancak analize dahil ettiğimiz bazı şirketlerin stok kalemleri çok düşük ve hiç olmadığından dolayı şirket performans değerlendirmesin anlamlı sonuçlar vermeyeceği düşünülerek analize dahil edilen oran gruplarından çıkarılmıştır.

Analizde kullanılan oranlar genel olarak kullanılmayan oranlarında açıklayıcısı olarak seçilmeye çalışıımıştır. Bir adet likidite oranı, beş adet borçluluk oranından, iki adet faaliyet oranından, iki adet de karlılık oranından yararlanılmıştır. Çok amaçlı karar verme yöntemlerinden en yaygın kullanılan TOPSIS yöntemi ile sektörün mali performansı analiz edilerek, Borsa İstanbul'da işlem gören enerji şirketleri derecelendirilmektedir. 


\section{TOPSIS YÖNTEMI}

Karar verme problemi, en uygun seçenekler arasından en iyi seçeneği belirleme sürecini kapsamaktadır. Çok değişkenli karar verme problemleri karşısında bir karar vermek durumunda olanlar için TOPSIS, ELECTRE, AHP, Bulanık AHP, Bulanık TOPSIS gibi çeşitli çok amaçlı karar verme yöntemi bulunmaktadır. Çok amaçlı karar verme yöntemleri arasında son yıllarda yaygın olarak kullanılan yöntemlerden biri olan TOPSIS yöntemi, birden fazla kriter ve karar vericiye dayalı değerlendirmelerde başarılı bir yöntem olarak kullanılmaktadır.

TOPSIS (Technigue for Order Preference by Similarity to Ideal Solution) yöntemi karar amaçlı yapılan çalışmalarda çok sık kullanılan yöntemlerden biridir. TOPSIS yöntemi ELECTRE yöntemine alternatif olarak geliştirilmiş ve çoklu karar verme problemlerinin çözümünde en çok kullanılan yöntemlerinden birini oluşturmaktadır. TOPSIS yöntemi, Hwang\&Yoon (1981) tarafından çok kriterli karar verme tekniği olarak geliştirilmiştir. TOPSIS, pozitifideal çözüm(PIS) ile negatif-ideal çözüm (NIS) noktalarını belirlemeye çalışır. PIS, faydanın en yükseğe, maliyetin en düşük olduğu çözüm noktası iken NIS ise faydanın en düşük, maliyetin en yüksek olduğu çözüm noktasını ifade etmekte kullanılır. TOPSIS yaklaşımının temelinde en çok tercih edilen alternatifin sadece pozitif ideal çözüme en yakın olan değil aynı zamanda negatif ideal çözüme en uzak mesafede olan alternatif olduğu fikri yatmaktadır (Dumanoğlu \& Ergül, 2010).

TOPSIS'in karar vericiler tarafından sıkça kullanılıyor olmasının nedeni, sınırlı sayıda öznel (sübjektif) girdiye gereksinim duymasından kaynaklanmaktadır. Yöntemde kullanılan tek öznel değişken faktör ağırlıklarıdır. TOPSIS yönteminin temel üstünlükleri; basit ve anlaşılabilir, iyi bir hesaplama etkinliğine sahip olması ve basit bir matematiksel denklemden hareketle her bir alternatifin göreceli performansının ölçülmesine imkan sağlamasıdır (Yeh,2002)

Tablo 3: Çok Kriterli Karar Verme Tekniklerinin Karşılaştırılması

\begin{tabular}{|c|c|c|c|c|c|}
\hline ÇKKV Teknikleri & $\begin{array}{c}\text { Hesaplama } \\
\text { Zamanı }\end{array}$ & Basitlik & $\begin{array}{c}\text { Matematik } \\
\text { İşlemleri }\end{array}$ & Güvenilirlik & Veri Türü \\
\hline TOPSiS & Orta & Orta Kritik & Orta & Orta & Nicel \\
\hline AHP & Çok Fazla & Çok Kritik & Maksimum & Zayıf & Karışık \\
\hline MOORA & Çok Az & Çok Basit & Minimum & İyi & Nicel \\
\hline VIKOR & Az & Basit & Orta & Orta & Nicel \\
\hline ELECTRE & Fazla & Orta Kritik & Orta & Orta & Karışık \\
\hline PROMETHEE & Fazla & Orta Kritik & Orta & Orta & Karışı \\
\hline
\end{tabular}

Kaynak: (Vatansever \&Uluköy, 2013)

TOPSIS, Yoon ve Hwang tarafından 1980 yılında geliştirilmiştir ve ELECTRE yönteminin temel yaklaşımlarını kullanır. Karar noktalarının ideal çözüme yakınlığı ana prensibine dayanır ve çözüm süreci ELECTRE yöntemine nazaran daha kısadır. TOPSIS yöntemi 6 adımdan oluşan bir çözüm sürecini içerir. Yöntemin ilk iki adımı ELECTRE yöntemi ile ortaktır. Aşağıda TOPSIS yönteminin adımları tanımlanmıştır.

Adım 1: Karar Matrisinin ( $\boldsymbol{A})$ Oluşturulması: Karar matrisinin satırlarında üstünlükleri sıralanmak istenen karar noktaları, sütunlarında ise karar vermede kullanılacak değerlendirme faktörleri yer alır. A matrisi karar verici tarafından oluşturulan başlangıç matrisidir. Karar matrisi aşağıdaki gibi gösterilir:

$A_{i j}=\left[\begin{array}{cccc}a_{11} & a_{12} & \ldots & a_{1 n} \\ a_{21} & a_{22} & \ldots & a_{2 n} \\ \cdot & & & \cdot \\ \cdot & & & \cdot \\ \cdot & & & \cdot \\ a_{m 1} & a_{m 2} & \ldots & a_{m n}\end{array}\right]$ 
$A_{i j}$ matrisinde $\mathrm{m}$ karar noktası sayısını, $\mathrm{n}$ değerlendirme faktörü sayısını verir.

Adım 2: Standart Karar Matrisinin (R) Oluşturulması: Standart Karar Matrisi, A matrisinin elemanlarından yararlanarak ve aşağıdaki formül kullanılarak hesaplanır.

$$
r_{i j}=\frac{a_{i j}}{\sqrt{\sum_{k=1}^{m} a_{k j}^{2}}} \quad(\mathrm{i}=1, \ldots . ., \mathrm{m} ; \mathrm{j}=1, \ldots \ldots \ldots, \mathrm{n})
$$

R matrisi yandaki gibi elde edilir: $R_{i j}=\left[\begin{array}{cccc}r_{11} & r_{12} & \ldots & r_{1 n} \\ r_{21} & r_{22} & \ldots & r_{2 n} \\ \cdot & & & \cdot \\ \cdot & & & \cdot \\ \cdot & & & \cdot \\ r_{m 1} & r_{m 2} & \ldots & r_{m n}\end{array}\right]$

Adım 3: Ağırlıkı Standart Karar Matrisinin (V) Oluşturulması: Öncelikle değerlendirme faktörlerine ilişkin ağırık değerleri $\left(w_{i}\right)$ belirlenir $\left(\sum_{i=1}^{n} w_{i}=1\right)$. Daha sonra R matrisinin her bir sütunundaki elemanlar ilgili $w_{i}$ değeri ile çarpılarak V matrisi oluşturulur. V matrisi aşağıda gösterilmiştir:

$$
V_{i j}=\left[\begin{array}{cccc}
w_{1} r_{11} & w_{2} r_{12} & \ldots & w_{n} r_{1 n} \\
w_{1} r_{21} & w_{2} r_{22} & \ldots & w_{n} r_{2 n} \\
\cdot & & & \cdot \\
\cdot & & & \cdot \\
\cdot & & & \cdot \\
w_{1} r_{m 1} & w_{2} r_{m 2} & \ldots & w_{n} r_{m n}
\end{array}\right]
$$

Adım 4: İdeal $\left(A^{*}\right)$ ve Negatif ídeal $\left(A^{-}\right)$Çözümlerin Oluşturulması: TOPSIS yöntemi, her bir değerlendirme faktörünün monoton artan veya azalan bir eğilime sahip olduğunu varsaymaktadır.

İdeal çözüm setinin oluşturulabilmesi için V matrisindeki ağırlıklandırılmış değerlendirme faktörlerinin yani sütun değerlerinin en büyükleri (ilgili değerlendirme faktörü minimizasyon yönlü ise en küçüğü) seçilir. İdeal çözüm setinin bulunması aşă̆ıdaki formülde gösterilmiştir.

$$
A^{*}=\left\{\left(\max _{i} v_{i j} \mid j \in J\right),\left(\min _{i} v_{i j} \mid j \in J^{\prime}\right\}\right.
$$

(2) formülünden hesaplanacak set $A^{*}=\left\{v_{1}^{*}, v_{2}^{*}, \ldots, v_{n}^{*}\right\}$ şeklinde gösterilebilir. 
Negatif ideal çözüm seti ise, V matrisindeki ağırlıklandırılmış değerlendirme faktörlerinin yani sütun değerlerinin en küçükleri (ilgili değerlendirme faktörü maksimizasyon yönlü ise en büyüğü) seçilerek oluşturulur. Negatif ideal çözüm setinin bulunması aşağıdaki formülde gösterilmiştir.

$$
A^{-}=\left\{\left(\min _{i} v_{i j} \mid j \in J\right),\left(\max _{i} v_{i j} \mid j \in J^{\prime}\right\}\right.
$$

(3) formülünden hesaplanacak set $A^{-}=\left\{v_{1}^{-}, v_{2}^{-}, \ldots, v_{n}^{-}\right\}$şeklinde gösterilebilir.

Her iki formülde de $J$ fayda (maksimizasyon), $J$ ' ise kayıp (minimizasyon) değerini göstermektedir. Gerek ideal gerekse negatif ideal çözüm seti, değerlendirme faktörü sayısı yani m elemandan oluşmaktadır.

4. adımda ideal $A^{*}$ ve negatif ideal $A$ çözüm setleri oluşturulmuştur. $A^{*}$ seti için $\mathrm{V}$ matrisinin her bir sütunundaki en büyük değer, $A$ seti için $V$ matrisinin her bir sütunundaki en küçük değer seçilmiş ve setler kriterlerin amaca hizmet edişine göre düzenlenmiştir.

Adım 5: Ayırım Ölçülerinin Hesaplanması: TOPSIS yönteminde her bir karar noktasına ilişkin değerlendirme faktör değerinin İdeal ve negatif ideal çözüm setinden sapmalarının bulunabilmesi için Euclidian Uzaklık Yaklaşımından yararlanılmaktadır. Buradan elde edilen karar noktalarına ilişkin sapma değerleri ise İdeal Ayırım ( $S_{i}^{*}$ ) ve Negatif İdeal Ayırım $\left(S_{i}^{-}\right)$Ölçüsü olarak adlandırılmaktadır. İdeal ayırım $\left(S_{i}^{*}\right)$ ölçüsünün hesaplanması (4) formülünde, negatif ideal ayırım ( $S_{i}^{-}$) ölçüsünün hesaplanması ise (5) formülünde gösterilmiştir.

$$
\begin{aligned}
& S_{i}^{*}=\sqrt{\sum_{j=1}^{n}\left(v_{i j}-v_{j}^{*}\right)^{2}} \\
& S_{i}^{-}=\sqrt{\sum_{j=1}^{n}\left(v_{i j}-v_{j}^{-}\right)^{2}}
\end{aligned}
$$

Burada hesaplanacak $S_{i}^{*}$ ve $S_{i}^{-}$sayısı doğal olarak karar noktası sayısı kadar olacaktır.

Adım 6: İdeal Çözüme Göreli Yakınlığın Hesaplanması: Her bir karar noktasının ideal çözüme göreli yakınlığının ( $C_{i}^{*}$ ) hesaplanmasında ideal ve negatif ideal ayırım ölçülerinden yararlanılır. Burada kullanılan ölçüt, negatif ideal ayırım ölçüsünün toplam ayırım ölçüsü içindeki payıdır. İdeal çözüme göreli yakınlık değerinin hesaplanması aşağıdaki formülde gösterilmiştir.

$$
C_{i}^{*}=\frac{S_{i}^{-}}{S_{i}^{-}+S_{i}^{*}}
$$

Burada $C_{i}^{*}$ değeri $0 \leq C_{i}^{*} \leq 1$ aralığında değer alır ve $C_{i}^{*}=1$ ilgili karar noktasının ideal çözüme, $C_{i}^{*}=0$ ilgili karar noktasının negatif ideal çözüme mutlak yakınlığını gösterir.

Daha sonra bulunan $C_{i}^{*}$ değerleri büyüklük sırasına göre dizilerek karar noktalarının (alternatiflerin) önem sıraları belirlenmektedir. 


\section{PANEL VERI ANALIZi}

Panel veri analizi yöntemi, zaman boyutuyla ilgili yatay kesit verilerinin kullanılarak, iktisadi ilişkilerin tahmin edilmesidir. Panel veri analizi yöntemi ile yapılan çalışmalarda birimler ve zaman içinde birimlerde ortaya çıkan değişimler gösterilmektedir. Ayrıca panel veri analiziyle açıkça ölçülemeyen, sayısal olarak ifade edilemeyen faktörlerin etkileri de ölçülür. Bununla birlikte panel veri analizinde bireyler, ülkeler, firmalar ve hane halklarına ait yatay kesit gözlemleri, belli dönemleri kapsayacak şekilde bir araya getirilir (Tatoğlu, 2012: 2).

Bir zaman serisinin istatistiksel analizi yapılmadan önce, o seriyi yaratan sürecin zaman içerisinde sabit olup olmadığının yani serinin durağan olup olmadığının incelenmesi gerekmektedir. Durağan olmayan seriler arasında ekonometrik analizler yapıldığında, sahte regresyon denilen yanıltıcı bir sonuçla karşılaşılmakta, bir başka ifade ile geleneksel $t, F$ testleri ve $\mathrm{R}^{2}$ değerleri sapmalı sonuçlar verebilmektedir. Panel veri analizinden önce serilerin durağan olup olmadıkları test edilmesi gerekmektedir.

Çalışmada birim kök testlerinden olan Levin,Lin ve Chu panel birim kök testi, Fisher panel birim kök testlerinden Fisher ADF ve FisherPhilips ve Perron birim kök testleri kullanılmıştır.

Levin, Lin ve Chu panel birim kök testi, tüm birimlerin aynı otoregresif parametreye sahip olduğunu varsaymaktadır. Birim kök sınamasını sabitsiz, sabitli, sabitli-trendli olmak üzere üç farklı modelle test etmektedir. Sadece dengeli panele uygulanabilmektedir.

$$
\begin{aligned}
& \text { Model 1: } \Delta Y_{i t}=\rho Y_{i t-1}+u_{i t} \\
& \text { Model 2: } \Delta Y_{i t}=\alpha_{0 i}+\rho Y_{i t-1}+u_{i t} \\
& \text { Model 3: } \Delta Y_{i t}=\alpha_{0 i}+\alpha_{0 i} t+\rho Y_{i t-1}+u_{i t}
\end{aligned}
$$

Fisher testlerinde, önce her bir birim için birim kök testi yapılmakta ve daha sonra bu testlerden elde edilen $p$ değerleri tüm testi üretmek için kullanılmaktadır. Fisher ADF testi zaman serileri için klasik ADF testini, FisherPhilips ve Perron testi de zaman serileri için klasik Philips ve Perron testini her birim için uygulamaktadır. Fisher testlerinde, veri setinin dengeli panel olması şartı yoktur ve bireysel seriler boşluklara sahip olabilmektedirler. Bu özellik diğer testlere göre, esneklik sağlamaktadır.

Birim kök testlerinden sonra serilerin durağanlığı sağlandıktan sonra eşbütünleşme testleri yapılmaktadır. Eşbütünleşme testi ile seriler arasında kısa ve uzun dönem denge ilişkisinin var olup olmadığının incelendiği bir süreci temsil etmektedir. Pedroni $(1994,2004)$, temel hipotezi "eşbütünleşme yoktur" şeklinde olan yedi adet eşbütünleşme testi (dördü panel ve üçü grup test istatistiği ) önermiştir ve alternatif hipotez altında heterojenliğe izin verilmektedir. Pedroni eşbütünleşme testi aşağıdaki denklemle açıklanabilir.

$y_{i t}=\alpha_{i}+\delta_{i} t+\beta_{1 i} X_{1 i t}+\beta_{2 i} X_{2 i t}+\ldots+\beta_{M i} X_{M i t}+\varepsilon_{i t}$

Kao (1999) Panel Eşbütünleşme Testleri, DF(Dickey Fuller) ve ADF(Genelleştirilmiş Dickey Fuller) temelli testlerdir. Yapılan test de boş hipotez eşbütünleşmenin olmadığı $\left(H_{0}: \rho=1\right)$ şeklinde kurulmaktadır.

$y_{i t}=X_{i t} \beta+z_{i t} \gamma+\varepsilon_{i t}$

Panel veri analizinde yapılan eş-bütünleşme testlerinin sonuçlarına bağlı olarak panel nedensellik testi yapılmaktadır. Nedensellik ilişkisinin tespiti için bir gecikmeli hata düzeltme terimi ile genişletilmiş VAR modeli kullanılarak VECM tahmin edilebilir.

\section{ARAŞTIRMANIN BULGULARI}

Borsa İstanbul'da işlem gören "AKENR, AKSEN, AKSUE, ANELE, AVTUR, AYEN, AYGAZ, EMKEL, GEREL, IPEKE, PETKM, TRCAS, TUPRS, ZOREN” borsa kodlu 14 enerji şirketleri analiz kapsamına alınmıştır. Analizde kullanılan enerji şirketlerinin mali performanslarını incelemek üzere 2010-2014 dönemine ait yılsonu dönem mali tabloları kullanılmıştır.

Araştırmanın analizi iki aşamadan oluşmaktadır. Analizin ilk adımında; enerji sektörünün performansını açıklayacak finansal oranlar belirlenmekte ve ardından oran analizi metodu kullanılarak, finansal oranlar her bir enerji şirketi için ayrı ayrı hesaplanmaktadır. Araştırmada kullanılan finansal oranlar "Cari Oran, Finansal Kaldıraç 
Oranı, Özkaynaklar/Aktifler, Finansman Oranı, KVYK/Toplam Pasifler, Duran Varlıklar / Devamlı Sermaye, Aktif Devir Hızı, Özkaynak Devir Hızı, Özsermaye Karlılığı, Aktif Karlılığı” dır. Íkinci adımda ise, enerji şirketleri için hesaplanan finansal oranlar TOPSIS yöntemi kullanılarak, genel şirket performansını gösteren tek bir puana çevrilmektedir. Ardından enerji şirketlerinin sıralaması yapılarak, enerji şirketlerinin derecelendirilmesi tamamlanmaktadır. Enerji şirketlerinin 2010-2014 sürecinde yer alan beş dönem için ayrı ayrı genel performans puanları hesaplanarak, derecelendirmeleri yapılmaktadır. TOPSIS yönteminin uygulanmasında Excell 2010 programı kullanılmaktadır.

TOPSIS yönteminin uygulanmasında 1. Adım: Karar Matrisinin (A) oluşturulmasıdır. Karar matrisinin satırlarında üstünlükleri sıralanmak istenen karar noktaları, sütunlarında ise karar vermede kullanılacak değerlendirme faktörleri yer alır. A matrisi karar verici tarafından oluşturulan başlangıç matrisidir. Çalışmada 2010 yılı gösterimi örnek olarak gösterilecektir. Diğer yıllar için de aynı uygulamalar yapıldığından gösterilmeyecektir.

Adım 1: Karar Matrisinin (A) Oluşturulması: Çalışmada 14 karar noktası (Alternatifler-Şirketler) ve 10 değerlendirme faktörü (Kriterler-Finansal Oranlar) bulunmaktadır. Öncelikle TOPSIS yöntemi için (14X10) boyutlu Standart Karar Matrisi oluşturulmuştur. Buna göre çalışmaya konu olan işletmelerin 2010 yılı karar matrisi Tablo3'de ki gibidir.

Tablo 4: 2010 Dönemi Karar Verme Matrisi

\begin{tabular}{|l|c|c|c|c|c|c|c|c|c|c|}
\hline Şirketler & L1 & B1 & B2 & B3 & B4 & B5 & F1 & F2 & K1 & K2 \\
\hline AKENR & 0,5829 & 0,6003 & 0,3997 & 0,6659 & 0,2465 & 1,1364 & 0,2239 & 0,5601 & $-0,033$ & $-0,013$ \\
\hline AKSEN & 1,4831 & 0,6545 & 0,3455 & 0,5279 & 0,2696 & 0,8217 & 0,3822 & 1,1061 & 0,0717 & 0,0248 \\
\hline AKSUE & 12,749 & 0,1156 & 0,8844 & 7,6506 & 0,0127 & 0,8487 & 0,0698 & 0,0790 & 3,3994 & 3,0064 \\
\hline ANELE & 1,5971 & 0,6244 & 0,3756 & 0,6015 & 0,4254 & 0,5579 & 0,5804 & 1,5452 & 0,1061 & 0,0399 \\
\hline AVTUR & 145,64 & 0,0069 & 0,9931 & 144,90 & 0,0069 & 0,0018 & 128,90 & 129,79 & $-0,0469$ & $-0,0466$ \\
\hline AYEN & 1,4457 & 0,4718 & 0,5282 & 1,1194 & 0,1184 & 0,9402 & 0,2499 & 0,4731 & 0,1597 & 0,0843 \\
\hline AYGAZ & 1,9048 & 0,2817 & 0,7183 & 2,5501 & 0,2037 & 0,7686 & 1,6613 & 2,3128 & 0,1192 & 0,0857 \\
\hline EMKEL & 0,5215 & 0,6044 & 0,3956 & 0,6546 & 0,4299 & 1,3608 & 0,6236 & 1,5764 & $-0,0552$ & $-0,0218$ \\
\hline GEREL & 1,5985 & 0,5684 & 0,4316 & 0,7593 & 0,3005 & 0,7429 & 0,7949 & 1,8417 & $-0,0787$ & $-0,0340$ \\
\hline IPEKE & 2,5872 & 0,2171 & 0,7829 & 3,6052 & 0,1615 & 0,6944 & 0,5429 & 0,6935 & 0,2661 & 0,2083 \\
\hline PETKM & 1,6219 & 0,3264 & 0,6736 & 2,0635 & 0,2870 & 0,7496 & 1,2245 & 1,8180 & 0,0813 & 0,0548 \\
\hline TRCAS & 6,3424 & 0,0242 & 0,9758 & 40,252 & 0,0162 & 0,9120 & 0,0933 & 0,0956 & 0,2032 & 0,1983 \\
\hline TUPRS & 1,0499 & 0,7197 & 0,2779 & 0,3862 & 0,6357 & 0,9189 & 1,8800 & 6,7642 & 0,1917 & 0,0533 \\
\hline ZOREN & 0,4878 & 0,9399 & 0,0601 & 0,0640 & 0,3008 & 1,2204 & 0,1662 & 2,7636 & $-0,4816$ & $-0,0290$ \\
\hline
\end{tabular}

Adım 2: Standart Karar Matrisinin ( $R$ ) Oluşturulması: Tablo 4'de Normalize Edilmiş (Standart) Karar Matrisi, A matrisinin elemanlarından yararlanarak ve (1) numaralı denklem kullanılarak hesaplanmıştır.

Tablo 5: 2010 Dönemi Standart Karar Matrisi

\begin{tabular}{|l|c|c|c|c|c|c|c|c|c|c|}
\hline Şirketler & L1 & B1 & B2 & B3 & B4 & B5 & F1 & F2 & K1 & K2 \\
\hline AKENR & 0,004 & 0,310 & 0,172 & 0,004 & 0,221 & 0,341 & 0,002 & 0,004 & $-0,010$ & $-0,004$ \\
\hline AKSEN & 0,010 & 0,339 & 0,148 & 0,004 & 0,241 & 0,247 & 0,003 & 0,009 & 0,021 & 0,008 \\
\hline AKSUE & 0,087 & 0,060 & 0,380 & 0,051 & 0,011 & 0,255 & 0,001 & 0,001 & 0,981 & 0,994 \\
\hline ANELE & 0,011 & 0,323 & 0,161 & 0,004 & 0,381 & 0,168 & 0,005 & 0,012 & 0,031 & 0,013 \\
\hline AVTUR & 0,995 & 0,004 & 0,426 & 0,962 & 0,006 & 0,001 & 1,000 & 0,998 & $-0,014$ & $-0,015$ \\
\hline AYEN & 0,010 & 0,244 & 0,227 & 0,007 & 0,106 & 0,282 & 0,002 & 0,004 & 0,046 & 0,028 \\
\hline AYGAZ & 0,013 & 0,146 & 0,308 & 0,017 & 0,182 & 0,231 & 0,013 & 0,018 & 0,034 & 0,028 \\
\hline EMKEL & 0,004 & 0,313 & 0,170 & 0,004 & 0,385 & 0,409 & 0,005 & 0,012 & $-0,016$ & $-0,007$ \\
\hline GEREL & 0,011 & 0,294 & 0,185 & 0,005 & 0,269 & 0,223 & 0,006 & 0,014 & $-0,023$ & $-0,011$ \\
\hline IPEKE & 0,018 & 0,112 & 0,336 & 0,024 & 0,145 & 0,209 & 0,004 & 0,005 & 0,077 & 0,069 \\
\hline
\end{tabular}




\begin{tabular}{|c|c|c|c|c|c|c|c|c|c|c|}
\hline PETKM & 0,011 & 0,169 & 0,289 & 0,014 & 0,257 & 0,225 & 0,009 & 0,014 & 0,023 & 0,018 \\
\hline TRCAS & 0,043 & 0,013 & 0,419 & 0,267 & 0,015 & 0,274 & 0,001 & 0,001 & 0,059 & 0,066 \\
\hline TUPRS & 0,007 & 0,372 & 0,119 & 0,003 & 0,569 & 0,276 & 0,015 & 0,052 & 0,055 & 0,018 \\
\hline ZOREN & 0,003 & 0,486 & 0,026 & 0,000 & 0,269 & 0,367 & 0,001 & 0,021 & $-0,139$ & $-0,010$ \\
\hline TOPLAM & 1.227 & 3.184 & 3.367 & 1.366 & 3.056 & 3.506 & 1.066 & 1.164 & 1.126 & 1.194 \\
\hline
\end{tabular}

Adım 3: Ağırıklı Standart Karar Matrisinin (V) Oluşturulması: Bu adımda değerlendirme faktörlerine ilişkin ağırlık dereceleri $\left(W_{i}\right)$ belirlenir. Daha sonra bir önceki aşamada hesaplanan normalize edilmiş (standart) değerler, $\left(W_{i}\right.$ ) değerleri ile çarpılarak ağırlıklandırılmış standart değerler bulunur.

Değerlendirme faktörlerine ilişkin ağırlık dereceleri hesaplanırken öncelikle Tablo 5'deki her bir değerlendirme faktörünün (L1, B1, B2, B3 ...) 14 karar noktasının işletmeye ait sütun değerleri toplanmıştır. Daha sonra 10 kritere ilişkin bulunan bu değerler toplanarak toplam kriter değeri (20.255) hesaplanmıştır. Son olarak ise her bir kriterin sütun toplamı, kriterlerin toplam değerine bölünerek ağırlıklar hesaplanmıştır. Buna göre 2010 yılı değerlendirmede kriterlere ilişkin ağırlıklar $W_{1}=0.0606 \quad(1.227 / 20.255), \quad W_{2}=0.1572(3.184 / 20.255)$, $W_{3}=0.1662(3.367 / 20.255), W_{4}=0.0674(1.367 / 20.255), W_{5}=0.1509(3.056 / 20.255), W_{6}=0.1731(3.506 / 20.255)$, $W_{7}=0.0526(1.066 / 20.255), W_{8}=0.0575(1.164 / 20.255), W_{9}=0.0556(1.126 / 20.255), W_{10}=0.0589(1.194 / 20.255)$, şeklinde hesaplanmıştır.Oluşturulacak ağırlıklı standart karar matrisi için, R matrisinin sütunlarındaki değerler ilgili değerlendirme faktörü ağırlık değerleri ile çarpılmış ve $V$ matrisinin sütunları hesaplanmıştır. Tablo 6'da

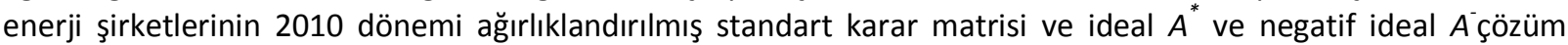
setleri yer almaktadır.

Tablo 6: 2010 Dönemi Ağırlıklandırılmış Standart Karar Matrisi

\begin{tabular}{|l|c|c|c|c|c|c|c|c|c|c|}
\hline Şirketler & L1 & B1 & B2 & B3 & B4 & B5 & F1 & F2 & K1 & K2 \\
\hline AKENR & 0.0002 & 0.0488 & 0.0285 & 0.0003 & 0.0333 & 0.0591 & 0.0001 & 0.0002 & -0.0005 & -0.0003 \\
\hline AKSEN & 0.0006 & 0.0532 & 0.0247 & 0.0002 & 0.0364 & 0.0427 & 0.0002 & 0.0005 & 0.0012 & 0.0005 \\
\hline AKSUE & 0.0053 & 0.0094 & 0.0631 & 0.0034 & 0.0017 & 0.0441 & 0.0000 & 0.0000 & 0.0545 & 0.0586 \\
\hline ANELE & 0.0007 & 0.0508 & 0.0268 & 0.0003 & 0.0574 & 0.0290 & 0.0002 & 0.0007 & 0.0017 & 0.0008 \\
\hline AVTUR & 0.0602 & 0.0006 & 0.0709 & 0.0649 & 0.0009 & 0.0001 & 0.0526 & 0.0574 & -0.0008 & -0.0009 \\
\hline AYEN & 0.0006 & 0.0384 & 0.0377 & 0.0005 & 0.0160 & 0.0489 & 0.0001 & 0.0002 & 0.0026 & 0.0016 \\
\hline AYGAZ & 0.0008 & 0.0229 & 0.0513 & 0.0011 & 0.0275 & 0.0400 & 0.0007 & 0.0010 & 0.0019 & 0.0017 \\
\hline EMKEL & 0.0002 & 0.0491 & 0.0282 & 0.0003 & 0.0580 & 0.0707 & 0.0003 & 0.0007 & -0.0009 & -0.0004 \\
\hline GEREL & 0.0007 & 0.0462 & 0.0308 & 0.0003 & 0.0406 & 0.0386 & 0.0003 & 0.0008 & -0.0013 & -0.0007 \\
\hline IPEKE & 0.0011 & 0.0177 & 0.0559 & 0.0016 & 0.0218 & 0.0361 & 0.0002 & 0.0003 & 0.0043 & 0.0041 \\
\hline PETKM & 0.0007 & 0.0265 & 0.0481 & 0.0009 & 0.0388 & 0.0390 & 0.0005 & 0.0008 & 0.0013 & 0.0011 \\
\hline TRCAS & 0.0026 & 0.0020 & 0.0696 & 0.0180 & 0.0022 & 0.0474 & 0.0000 & 0.0000 & 0.0033 & 0.0039 \\
\hline TUPRS & 0.0004 & 0.0585 & 0.0198 & 0.0002 & 0.0858 & 0.0478 & 0.0008 & 0.0030 & 0.0031 & 0.0010 \\
\hline ZOREN & 0.0002 & 0.0764 & 0.0043 & 0.0000 & 0.0406 & 0.0634 & 0.0001 & 0.0012 & -0.0077 & -0.0006 \\
\hline
\end{tabular}

Adım 4: İdeal $\left(A^{*}\right)$ ve Negatif i̇deal $\left(A^{-}\right)$Çözümlerin Oluşturulması: Bu adımda ideal $A^{*}$ ve negatif ideal $A^{-}$ çözüm setleri oluşturulmuştur. $A^{*}$ seti için $\mathrm{V}$ matrisinin her bir sütunundaki en büyük değer, $A$ seti için $V$ matrisinin her bir sütunundaki en küçük değer seçilmiş ve kümeler, kriterlerin amaca hizmet edişine göre düzenlenmiştir.

$$
A^{*}=\left\{\left(\max _{i} v_{i j} \mid j \in J\right),\left(\min _{i} v_{i j} \mid j \in J^{\prime}\right\}\right.
$$




$$
A^{-}=\left\{\left(\min _{i} v_{i j} \mid j \in J\right),\left(\max _{i} v_{i j} \mid j \in J^{\prime}\right\}\right.
$$

Buna göre ;

$$
\begin{gathered}
A^{*}=\left\{\begin{array}{c}
0,0602 ; 0,0764 ; 0,0709 ; 0,0649 ; 0,0858 ; 0,0707 ; 0,0526 ; 0,0574 ; \\
0,0545 ; 0,0586
\end{array}\right\} \\
A^{-}=\left\{\begin{array}{c}
0,0002 ; 0,0006 ; 0,0043 ; 0,0000 ; 0,0009 ; 0,0001 ; 0,000 ; 0,000 ; \\
-0,0077 ;-0,0009
\end{array}\right\}
\end{gathered}
$$

Adım 5: Ayırım Ölçülerinin Hesaplanması: Alternatifler arasındaki mesafe, $n$ boyutlu Öklit (Euclidean) uzaklık yaklaşımından yararlanılarak bulunmaktadır. Her alternatifin pozitif ideal çözümden olan mesafesi $\left(S_{i}^{*}\right)$ ve negatif ideal çözümden olan ( $S_{i}^{-}$) ölçüsü (4) formülünden ve (5) formülünden yararlanılarak hesaplanmıştır.

$$
\begin{aligned}
& S_{i}^{*}=\left\{\begin{array}{c}
0,1604 ; 0,1607 ; 0,1586 ; 0,1579 ; 0,1566 ; 0,1660 ; 0,1645 ; 0,1536 ; 0,1608 ; \\
0,1672 ; 0,1610 ; 0,1739 ; 0,1510 ; 0,1661
\end{array}\right\} \\
& S_{i}^{-}=\left\{\begin{array}{c}
0,0865 ; 0,0796 ; 0,1137 ; 0,0845 ; 0,1354 ; 0,0725 ; 0,0714 ; 0,1059 ; 0,0767 ; \\
0,0696 ; 0,0749 ; 0,0835 ; 0,1149 ; 0,1065
\end{array}\right\}
\end{aligned}
$$

Adım 6: İdeal Çözüme Göreli Yakınlığın Hesaplanması: Her bir karar noktasının ideal çözüme göreli yakınlığının ( $C_{i}^{*}$ ) hesaplanmasında ideal ve negatif ideal ayırım ölçülerinden yararlanılır. Burada kullanılan ölçüt, negatif ideal ayırım ölçüsünün toplam ayııım ölçüsü içindeki payıdır. İdeal çözüme göreli yakınlık değerinin hesaplanması (6) formülde gösterilmiştir.

2010 yılına ait $C_{i}^{*}$ değeri $0 \leq C_{i}^{*} \leq 1$ aralığında değer alır ve $C_{i}^{*}=1$ ilgili karar noktasının ideal çözüme, $C_{i}^{*}=0$ ilgili karar noktasının negatif ideal çözüme mutlak yakınlığın göstermektedir. Tablo 6 'da enerji şirketlerinin 2010 dönemi ideal çözüme göreli yakınlık değerleri hesaplanmaktadır.

Tablo 7: 2010 Dönemi İdeal Çözüme Göreli Yakınlık Değerleri

\begin{tabular}{|l|l|}
\hline Şirketler & $\mathbf{C}^{*}$ \\
\hline AKENR & $0,0866 /(0,0866+0,1604)=\mathbf{0 , 3 5 0 5}$ \\
\hline AKSEN & $0,0796 /(0,0796+0,1608)=\mathbf{0 , 3 3 1 3}$ \\
\hline AKSUE & $0,1137 /(0,1137+0,1587)=\mathbf{0 , 4 1 7 4}$ \\
\hline ANELE & $0,0846 /(0,0846+0,1580)=\mathbf{0 , 3 4 8 7}$ \\
\hline AVTUR & $0,1354 /(0,1354+0,1567)=\mathbf{0 , 4 6 3 6}$ \\
\hline AYEN & $0,0726 /(0,0726+0,1660)=\mathbf{0 , 3 0 4 1}$ \\
\hline AYGAZ & $0,0714 /(0,0714+0,1645)=\mathbf{0 , 3 0 2 7}$ \\
\hline EMKEL & $0,1060 /(0,1060+0,1536)=\mathbf{0 , 4 0 8 2}$ \\
\hline GEREL & $0,0767 /(0,0767+0,1608)=\mathbf{0 , 3 2 3 0}$ \\
\hline IPEKE & $0,0697 /(0,0697+0,1673)=\mathbf{0 , 2 9 4 1}$ \\
\hline PETKM & $0,0750 /(0,0750+0,1610)=\mathbf{0 , 3 1 7 7}$ \\
\hline TRCAS & $0,0836 /(0,0836+0,1740)=\mathbf{0 , 3 2 4 5}$ \\
\hline TUPRS & $0,1149 /(0,1149+0,1510)=\mathbf{0 , 4 3 2 2}$ \\
\hline ZOREN & $0,1065 /(0,1065+0,1662)=\mathbf{0 , 3 9 0 6}$ \\
\hline
\end{tabular}

Daha sonra bulunan $C_{i}^{*}$ değerleri büyüklük sırasına göre dizilerek karar noktalarının (alternatiflerin) önem sıraları belirlenmektedir. 
Tablo 8: Enerji Şirketlerinin Puanları ve Sıralamaları

\begin{tabular}{|l|c|c|}
\hline \multirow{2}{*}{ ŞiRKETLER } & \multicolumn{2}{|c|}{$\mathbf{2 0 1 0}$} \\
\cline { 2 - 3 } AVTUR & 0.463583 & SIRA \\
\hline TUPRS & 0.432156 & 1 \\
\hline AKSUE & 0.417443 & 2 \\
\hline EMKEL & 0.408242 & 3 \\
\hline ZOREN & 0.390573 & 4 \\
\hline AKENR & 0.350503 & 5 \\
\hline ANELE & 0.348665 & 6 \\
\hline AKSEN & 0.331314 & 7 \\
\hline TRCAS & 0.324497 & 8 \\
\hline GEREL & 0.322992 & 9 \\
\hline PETKM & 0.317722 & 10 \\
\hline AYEN & 0.304091 & 11 \\
\hline AYGAZ & 0.302747 & 12 \\
\hline IPEKE & 0.294107 & 13 \\
\hline
\end{tabular}

Tablo 8'de enerji şirketlerinin puanlarının sıralanmaları yer almaktadır. Buna göre; 2010 döneminde enerji şirketleri arasında, değerlendirme faktörlerinden seçilen 10 adet rasyoya bağlı olarak gerçekleştirilen analizde, en iyi performansı AVTUR, en kötü performansı da IPEKE enerji şirketleri gerçekleştirmektedir. 2010 dönemi enerji şirketleri “AVTUR(1),TUPRS(2), AKSUE(3), EMKEL(4), ZOREN(5), AKENR(6),ANELE(7), AKSEN(8), TRCAS(9), GEREL(10), PETKM(11), AYEN(12),AYGAZ(14), IPEKE(12)," olarak sıralanmıştır.

2010 yılı için yapılan çalışmalar sırasıyla 2011, 2012, 2013, 2014 içinde yapılmıştır. Elde edilen sonuçlar aşağıdaki tablo 9'da gösterilmiştir.

Tablo 9: (2010-2014) Yılları Arasında Enerji Sektöründe Faaliyet Gösteren Şirketlerin “C” Değerleri ve Başarı Durumu

\begin{tabular}{|c|c|c|c|c|c|c|c|c|c|c|}
\hline \multirow{2}{*}{$\begin{array}{l}\text { Sira } \\
\text { No }\end{array}$} & \multicolumn{2}{|c|}{2010} & \multicolumn{2}{|c|}{2011} & \multicolumn{2}{|c|}{2012} & \multicolumn{2}{|c|}{2013} & \multicolumn{2}{|c|}{2014} \\
\hline & $\mathrm{C}^{*}$ & ŞíRKET & $\mathrm{C}^{*}$ & ŞIRKET & $\mathrm{C}^{*}$ & ŞiRKET & $\mathrm{C}^{*}$ & ŞíRKET & C* & ŞíRKET \\
\hline 1 & 0.4635 & AVTUR & 0.3978 & AKSUE & 0.5156 & TUPRS & 0.5580 & TUPRS & 0.5765 & TUPRS \\
\hline 2 & 0.4321 & TUPRS & 0.3928 & TUPRS & 0.4707 & AKSUE & 0.4491 & IPEKE & 0.4446 & AYGAZ \\
\hline 3 & 0.4174 & AKSUE & 0.3000 & AVTUR & 0.3531 & AYGAZ & 0.4405 & AYGAZ & 0.4360 & AVTUR \\
\hline 4 & 0.4082 & EMKEL & 0.2893 & AYGAZ & 0.3508 & PETKM & 0.4059 & PETKM & 0.4064 & IPEKE \\
\hline 5 & 0.3905 & ZOREN & 0.2658 & PETKM & 0.3450 & AVTUR & 0.3989 & GEREL & 0.3800 & GEREL \\
\hline 6 & 0.3505 & AKENR & 0.2622 & TRCAS & 0.3290 & ZOREN & 0.3936 & AKSUE & 0.3573 & ANELE \\
\hline 7 & 0.3486 & ANELE & 0.2570 & ZOREN & 0.3017 & IPEKE & 0.3721 & EMKEL & 0.3446 & PETKM \\
\hline 8 & 0.3313 & AKSEN & 0.2539 & GEREL & 0.3000 & EMKEL & 0.3694 & AVTUR & 0.3428 & ZOREN \\
\hline 9 & 0.3244 & TRCAS & 0.2525 & IPEKE & 0.2970 & GEREL & 0.3513 & ANELE & 0.3314 & EMKEL \\
\hline 10 & 0.3229 & GEREL & 0.2485 & EMKEL & 0.2960 & AKSEN & 0.3406 & ZOREN & 0.3187 & AKSEN \\
\hline 11 & 0.3177 & PETKM & 0.2432 & AKSEN & 0.2797 & ANELE & 0.3355 & AYEN & 0.3004 & AKENR \\
\hline 12 & 0.3040 & AYEN & 0.2326 & ANELE & 0.2620 & AYEN & 0.3252 & AKSEN & 0.2829 & AKSUE \\
\hline 13 & 0.3027 & AYGAZ & 0.2320 & AKENR & 0.2491 & AKENR & 0.2790 & AKENR & 0.2768 & AYEN \\
\hline 14 & 0.2941 & IPEKE & 0.2203 & AYEN & 0.2114 & TRCAS & 0.2456 & TRCAS & 0.2440 & TRCAS \\
\hline
\end{tabular}

Tablo 9'da ideal çözüme göreceli yakınlığı sonucunda şirketlerin " $C$ " değerleri verilmiştir. Tablo 10 'da şirketler bazında yıllık değişim sıralama olarak gösterilmiştir. 
Tablo 10: (2010 - 2014) Yılları Arasında Enerji Sektöründe Faaliyet Gösteren Şirketlerin Başarı Durumunun Yıllar Bazındaki Değişimi

\begin{tabular}{|c|c|c|c|c|c|c|c|c|c|c|}
\hline \multirow{3}{*}{$\begin{array}{c}\text { Sira } \\
\text { No }\end{array}$} & \multirow{3}{*}{ Şirketler } & \multirow{2}{*}{\multicolumn{5}{|c|}{ TOPSIS SIRALAMA SONUÇLARI }} & \multicolumn{4}{|c|}{$\begin{array}{l}\text { (2010-2014) ARASI HISSE SENETLERININ BORSADAKi } \\
\text { iSTATiSTiKi DEĞERLERi }\end{array}$} \\
\hline & & & & & & & \multicolumn{2}{|c|}{$\begin{array}{c}\text { FIYATLARINA AiT } \\
\text { iSTATiSTiKi DEĞERLERi }\end{array}$} & \multicolumn{2}{|c|}{$\begin{array}{c}\text { GETIRILERINE AiT } \\
\text { isTATiSTiKi DEĞERLERi }\end{array}$} \\
\hline & & 2010 & 2011 & 2012 & 2013 & 2014 & Ort. & Std. Sapma & Ort. & Std. Sapma \\
\hline 1 & AKENR & 6 & 13 & 13 & 13 & 11 & 1.780 & 0.609 & -0.00076 & 0.0224 \\
\hline 2 & AKSEN & 8 & 11 & 10 & 12 & 10 & 3.654 & 0.948 & -0.00069 & 0.0215 \\
\hline 3 & AKSUE & 3 & 1 & 2 & 6 & 12 & 5.457 & 1.150 & -0.00050 & 0.0211 \\
\hline 4 & ANELE & 7 & 12 & 11 & 9 & 6 & 1.722 & 0.457 & -0.00077 & 0.0203 \\
\hline 5 & AVTUR & 1 & 3 & 5 & 8 & 3 & 2.210 & 0.761 & -0.00010 & 0.0433 \\
\hline 6 & AYEN & 12 & 14 & 12 & 11 & 13 & 1.652 & 0.347 & -0.00020 & 0.0221 \\
\hline 7 & AYGAZ & 13 & 4 & 3 & 3 & 2 & 7.590 & 1.247 & 0.00077 & 0.0180 \\
\hline 8 & EMKEL & 4 & 10 & 8 & 7 & 9 & 1.494 & 0.590 & -0.00034 & 0.0300 \\
\hline 9 & GEREL & 10 & 8 & 9 & 5 & 5 & 1.320 & 0.182 & 0.00018 & 0.0216 \\
\hline 10 & IPEKE & 14 & 9 & 7 & 2 & 4 & 3.072 & 1.276 & -0.0012 & 0.0310 \\
\hline 11 & PETKM & 11 & 5 & 4 & 4 & 7 & 2.604 & 0.510 & 0.00062 & 0.0189 \\
\hline 12 & TRCAS & 9 & 6 & 14 & 14 & 14 & 2.400 & 0.461 & -0.00045 & 0.0216 \\
\hline 13 & TUPRS & 2 & 2 & 1 & 1 & 1 & 38.986 & 8.045 & 0.00060 & 0.0206 \\
\hline 14 & ZOREN & 5 & 7 & 6 & 10 & 8 & 1.389 & 0.432 & 0.00001 & 0.0267 \\
\hline
\end{tabular}

Analiz sürecinde yıllık olarak 14 şirket için " $C$ " değerleri elde edilmiş ve çıkan sonuçlarına göre her yıl 14 şirket kendi aralarında sıralanmıştır. Çalışmanın 2. kısmında hisse senetlerine ait 5 yılık ortalama fiyatları ve getirileri standart sapmalarıyla beraber tabloda gösterilmiştir. TOPSIS sonuçlarında sıralama olarak önde olan şirketlerden TUPRS, AYGAZ, IPEKE, AKSUE, AVTUR gibi firmaların 5 yıllık ortalama hisse fiyatlarının yüksek olduğu görülmektedir. Bu sonuç diğer bir şekilde ifade edildiğinde mali analizde yararlanılarak şirket oranlarının kullanılmasıyla elde edilen TOPSIS sonuçlarında karşılaştırmalı olarak iyi olan şirketlerin hisse senedi fiyatlarının yüksek olduğu söylenebilir. Çalışmanın bundan sonraki kısmında bu sonuca dayanarak şirketlerin TOPSIS sonuçlarından elde edilen " $C$ " değerleri ile şirketlerin hisse senedi ortalama getirileri arasında bir ilişki olup olmadığı panel veri analizi ile test edilmiştir. Bunun için değişken olarak seçilen TOPSIS skorları ("C") ile yıllık ortalama hisse senedi getirileri arasında kısa dönemli bir ilişkinin olup olmadığını test etmeden önce her iki değişkene ait birim kök testleri yapılarak serilerin durağan olup olmadıkları tespit edilmeye çalışılmıştır. Bunun için panel veri analizinde kullanılan Levin,Lin\&Chu $t^{*}$, ADF, PP (1979) birim kök testleri değişkenler için uygulanmıştır.

Tablo 11: Değişkenlerin Birim Kök Test Sonuçları (Düzeyde)

\begin{tabular}{|c|c|c|c|}
\hline Değişkenler & Levin, Lin \&Chu t & ADF & PP \\
\hline \multirow{2}{*}{ Getiri } & -16.1609 & 66.1824 & 73.5161 \\
\cline { 2 - 4 } & $(0.000)$ & $(0.000)$ & $(0.000)$ \\
\hline \multirow{2}{*}{ C } & -26.4338 & 62.5441 & 86.7031 \\
\cline { 2 - 4 } & 0.000 & 0.000 & 0.000 \\
\hline
\end{tabular}

Değişkenlere ait durağanlık test sonuçları Tablo 11'de gösterilmiştir. Birim kök için testler aşağıda verilmiştir. $\mathrm{H}_{0}$ : Değişken durağan değildir. Seriler birim kök içermektedir. $\mathrm{H}_{1}$ : Değişken durağandır. Seriler birim kök içermezler.

Tablo 11'e bakıldığında \%1 anlamlık düzeyinde $\mathrm{H}_{0}$ hipotezinin reddedildiği görülmektedir. Getiri ve " $\mathrm{C}$ " için Levin, Lin \&Chu t ${ }^{*}$, ADF ve PP testlerinde olasılık değerleri (0.000) olup (0.05)'den küçüktür. Buda değişkenlerin birim kök içermediği yani değişkenlerin durağan olduğu anlaşılmaktadır.

Değişkenlerin durağanlık analizinden sonra değişkenler arasında kısa dönemli bir eş-bütünleşme (Kointegrasyon) olup olmadığı test edilmiştir. Eş-bütünleşme sonuçları Tablo 12'de gösterilmiştir. 
Tablo 12: Getiri ve C Değişkenleri Arasındaki Panel Eş-bütünleşme Testi Sonuçları

\begin{tabular}{|l|l|c|c|}
\hline Test Türleri & Test İstatistikleri & İstatistik Değeri & Olasılık \\
\hline \multirow{4}{*}{ Pedroni (Engle- GrangerBased) } & Panel v- İstatistiği & -2.0135 & 0.9780 \\
\cline { 2 - 4 } & Panel rho-İstatistiği & -0.9434 & 0.1727 \\
\cline { 2 - 4 } & Panel PP-istatistiği & -12.1055 & 0.0000 \\
\cline { 2 - 4 } & Panel ADF-istatistiği & -9.6222 & 0.0000 \\
\cline { 2 - 4 } & Grup rho-istatistiği & 0.9973 & 0.8407 \\
\cline { 2 - 4 } & Grup PP-isstatistiği & -16.8388 & 0.0000 \\
\cline { 2 - 4 } & Grup ADF-istatistiği & -12.1996 & 0.0000 \\
\hline Kao(Engle-GrangerBased) & ADF & -10.6018 & 0.0000 \\
\hline
\end{tabular}

Değişkenler arasındaki Eş-bütünleşme testinde test şekli olarak sabitteki eş-bütünleşme sonuçlarına Tablo 12'de yer verilmiştir. Trenddeki test için 5 yıllık veri aralığı anlamlı sonuçlar vermemektedir. Bunun için eş-bütünleşme sonuçlarını anlamlı şekilde veren sabitteki kısa dönemli etkileşim test edilmiştir. Bunun için yaygın olarak kullanılan Pedroni ve Kao testleri yapılmıştır. Pedroni (Engle- GrangerBased) test sonuçlarında Panel PP-i̇statistiği, Panel ADF-i̇statistiği, Grup PP-İstatistiği ve Grup ADF-İstatistiğinde Olasık değerleri (0.05)'in altında çıkmıştır. Bununla birlikte Kao (Engle-GrangerBased) testinde ADF değerinin olasılık değeri (0.05)'in altında çıkmıştır. Bu sonuçlara göre her iki testde kısa dönemde "getiri" ve " $C$ " arasında bir eş-bütünleşmenin olduğu sonucuna ulaşıımıştır. Yani kısa dönemde "Getiri" ve "C" arasında bir etkileşim vardır. Değişkenler arasındaki eşbütünleşme sonuçlarından sonra değişkenler arasındaki nedensellik analizi için Granger Nedensellik testi yapılmıştır. Test sonuçları Tablo 13'de gösterilmiştir.

Tablo 13: Değişkenler arasındaki Granger Nedensellik Testi Sonuçları

\begin{tabular}{|c|c|c|c|c|c|}
\hline Modeller & Bağımlı Değişken & Bağımsız Değişken & F İstatistiği & Olasılık Değ. & Etki \\
\hline $\mathbf{1}$ & Getiri & C & 2.6245 & 0.1112 & YOK \\
\hline $\mathbf{2}$ & C & Getiri & 1.8379 & 0.1809 & YOK \\
\hline
\end{tabular}

Tablo 13'de Granger Nedensellik testi sonuçlarına bakıldığında bağımlı değişken Getiri olarak alındığında bağımsız değişken "C"değeri olarak alındığında olasılık değerinin (0.1112)'i olup (0.05)'den büyük olduğundan dolayı " $C$ " için Getirinin bir sebebi olmadığı söylenebilir. Yine aynı şekilde " $C$ " bağımlı değişken olduğunda Getiri bağımsız değişken olduğunda olasılık değeri (0.1809) olup (0.05)'den büyük olduğundan Getiri için "C" nin bir sebebi olmadığı söylenebilir. Sonuç olarak değişkenler arasında bir nedensellik ilişkisinin olmadığını görülmektedir.

\section{SONUÇLAR}

Tablo 10 sonuçlarına bakıldığına şirketlerinin sıralamada gösterdikleri performansla hisse fiyatları arasında doğrusal bir ilişkinin olduğu görülmektedir. Bu sonuca mali analiz açısından başarılı finansal oranlara sahip şirketlerin hisse senedi fiyatlarının finansal piyasalarda yüksek fiyatlanmaktadır. Çalışmanın ikinci kısmında TOPSIS sonucu olan " $C$ " değerleri ile şirketin hisse senedi getirileri arasındaki kısa dönemli bir ilişki olup olmadığı test edilmiştir. Tablo 12'deki sonuçlara bakıldığında değişkenler arasında bir eş-bütünleşmenin olduğu görülmektedir. Tablo 13'e baktığımızda her ne kadar değişkenler arasında bir eş-bütünleşme olsa da değişkenlerin bir birinin açıklayıcısı olmadığı sonucuna erişilmiştir. Değişkenler arasında bir nedensellik ilişkisi tespit edilememiştir. Her bir değişken diğer bir değişkenin granger’ı (sebebi) değildir. Sonuç olarak kısa dönemli bir ilişkinin olmadığına ulaşılmıştır. Diğer bir ifadeyle şirketlerin o yılki mali performans ölçüt değerleri ile o yıl için hisse senedi getirileri arasında bir etki olmadığına ulaşılmıştır.

Finansal piyasa yatırımcıları hisse senedine yatırım yaparken sadece şirket mali verilerine bakarak yatırım yapmamaktadır. Yatırımcılar birden fazla nedenden etkilenerek yatırım yapmaktadır. Yatırımcı beklentisi, hisse senedinin gelecekte durumu, spekülatif hareket gibi bir çok faktör hisse senedi yatırımcısını etkilemektedir. Çalışmamızda bir kısıt da sürenin kısa olmasıdır. Ayrıca yatırımcılar homojen yatırım setine sahiptir. Hisse senedi yatırımcısı için sadece bu 14 şirket arasında bir yatırım tercihi yoktur. 


\section{KAYNAKÇA}

Acar, M. “Tarımsal İ̧letmelerde Finansal Performans Analizi”. Erciyes Üniversitesi Iktisadi ve Idari Bilimler Fakültesi Dergisi,2003, $20,21-37$.

Akbulut, R. ve Rençber, Ö.F. (2015). BiST'te İmalat Sektöründeki İşletmelerin Finansal Performansları Üzerine Bir Araştırma, Muhasebe ve Finansman Dergisi, 65, 118-136.

Akdoğan, N. \&Tenker, N.,Finansal Tablolar ve Mali Analiz Teknikleri, 13. Baskı, Gazi Kitabevi,2007

Berk,N.,Finansal Yönetim, Türkmen Kitabevi, 9. Baskı, 2007

Borsa İstanbul (2015) , (http://www.borsaistanbul.com), erişim:10.05.2015

Bülbül, S. \& Köse, A., "Türk Gıda Şirketlerinin Finansal Performansının Çok Amaçlı Karar Verme Yöntemleriyle Değerlendirilmesi”http://edergi.atauni.edu.tr/atauniiibd/article, Erişim 21.05.2015

Crowther, D.,Managing Finance-A SociallyResponsibleApproach, Burlington: ElsevierButterworth- Heinemann, 2004

Çonkar, K., vd. "IMKB Kurumsal Yönetim Endeksi'ndeki (XKURY) Firmaların Finansal Performanslarının TOPSiS Yöntemi İle Ölçümü ve Kurumsal Yönetim Notu ile Analizi." iktisat Fakültesi Mecmuası 61.1 (2011): 81-115.

Deng, H.,Yeh, C.H.\& WILLIS,R.J., "InterCompanyComparison Using Modified TOPSIS WithObjectiveWeights", Journal of Computers\& Operations Research, Vol.27, Issue 10, September 2000, ss. 963-973

Dumanoğlu, S. \& Ergül, N. “ İmkb’de İşlem Gören Teknoloji Şirketlerinin Mali Performans Ölçümü”, Muhasebe ve Finansman Dergisi, 2010, 48, 101-111

Eleren, A., “ Kuruluş Yeri Seçiminde Fuzzy TOPSIS Yöntemi ille Belirlenmesi: Deri Sektörü Örneği”, Akdeniz iïBF. Dergisi, Cilt 46, Sayı 3, Eylül 2007, ss. 9-22

Ergül, N.,İmkb'de İşlem Gören Enerji Şirketlerinin Mali Performanslarının TOPSıS Yöntemi İle Analizi, Beta Yayınları 1. Baskı, 2010

Feng, C.M. \&Wang, R.T., " ConsideringThe Financial Ratios On ThePerformance Evaluation Of HighwayBusIndustry”, Transport Reviews, Vol. 21. No. 4, 2001, ss. $449-467$

Feng, C.M. \&Wang, R.T., "Performance Evaluation ForAirlinesIncludingTheConsideration of Financial Ratios" , Journal of Air Transport Management, Vol. 6, 2000, ss. 133-142

Hitchner, J. R.,FinancialValuation Applications andModels, New Jersey: John Wiley\&Sons, Inc. 2003

Hwang, C.L \& K. Yoon, K. , MultipleAttributeDecisionMaking, Springer-Verlag, Berlin, 1981

Kalaycı, Şeref, and Abdülmecit Karataş. "Hisse Senedi Getirileri ve Finansal Oranlar İlişkisi: iMKB' de Bir Temel Analiz Araştırması." Muhasebe ve Finansman Dergisi 27 (2005): 146-157.

KAP (Kamuyu Aydınlatma Platformu) (2015), https://www.kap.gov.tr/ (erişim 15.05.2015)

Karaca, Süleyman Serdar, and Eşref Savaş BAŞCı. "Hisse Senedi Performansını Etkileyen Rasyolar ve iMKB 30 Endeksinde 2001-2009 Dönemi Panel Veri Analizi." Süleyman Demirel Üniversitesi Iktisadi ve Idari Bilimler Fakültesi Dergisi 16.3 (2011).

Mahmoodzadeh S., vd. , "Project Selectionby Using Fuzzy AHP and TOPSIS Technigue”, World Academy of Science,

EngineeringandTechnology, 30, 333-338

Osteryoung, J. \&Constand R.L., " Financial Ratios in LargePublicand Small PrivateFirms”, Journal of Small Business Management,30 (3), 1992, $35-46$

Shıh, H.S.,Shyur, H.J., \& Lee, E.S. “ An extension of TOPSIS ForGroupDecisionMaking”, Mathematical andComputerModelling, Vol. 45, No 7-8, April 2007, ss. 801-813

Şalvarcı, Ahmet. "Finansal Oranlar ile Hisse Senedi Getirileri Arasındaki ilişkinin Analizi: iMKB İmalat Sektörü Üzerine Bir Araştırma”, Muhasebe ve Finansman Dergisi, Sayı: 48, s. 130, 2010

Tatoğlu, Ferda Yerdelen. "Panel veri ekonometris: stata uygulamalı”. Beta Basım Yayın, 2012.

Uygurtürk, H. \& Korkmaz, T. , “Finansal Performansın TOPSIS Çok Kriterli Karar Verme Yöntemi İle Belirlenmesi: Ana Metal Sanayi İ̧letmeleri Üzerine Bir Uygulama" Eskişehir Osmangazi Üniversitesi iiBF Dergisi, Ekim 2012, 7(2), ss. 95-115

Vatansever, K.,\&Uluköy, M. (2013). “Kurumsal kaynak planlaması sistemlerinin bulanık ahp ve bulanık moora yöntemleriyle seçimi: Üretim sektöründe bir uygulama." Celal Bayar Üniversitesi Sosyal Bilimler Dergisi, 11(2), 274-293. 
Walton, P. , “Applying FMCDM toEvaluate Financial Performance of DomesticAirlines in Taiwan”, ExpertSystemswithApplications: An International Journal, 34 (3), 2008, ss. 1837-1845

Yalçıner, Kürşat, Murat Atan, and Derviş Boztosun. "Finansal oranlarla hisse senedi getirileri arasındaki ilişki." Muhasebe Finansman Dergisi 27 (2005): 176-187.

Yeh, C,H., "A problem BasedSelection Of Multi-AttributeDecision-MakingMethods", Journal of International Transactions in OperationalResearch, Vol.9, 2002, ss. 169-181

Yurdakul, M. ve Y.T, İç. "Türk Otomotiv Firmalarının Performans Ölçümü ve Analizine Yönelik TOPSıS Yöntemini Kullanan Bir Örnek Çalışma", Gazi Uni. Muh. Mim. Fak. Dergisi,2003, 18(1), 1-18.

Yükçü, S. \&Atağan, G. , “TOPSIS Yöntemine Göre Performans Değerleme”, Journal of Accounting and Finance, january, 2010 